initial $/ \mathrm{n} /$ and the absence of $/ \mathrm{r} /$ in spoken Lao. Grammatically, too, there are close similarities to Thai: word order is subject-verb-object, nouns and verbs are not inflected, the pronominal system is complex and capable of conveying subtle degrees of relative status and intimacy. 'Classifiers' or 'count words' are used in noun phrases involving numbers.

Words of purely Lao origin are often monosyllabic. Sanskrit and Pali borrowings are numerous, and where they coexist with an indigenous Lao word they reflect a more formal or literary style. Other sources of loan words are Thai, Chinese, and Cambodian, although with Thai and Lao sharing many common basic words, the extent of Lao borrowing can be overestimated; many relatively recently coined Thai words have, however, been consciously absorbed into Lao. Despite the country's former colonial status, French loan words are relatively few.

\section{Sample of Lao with Translation}

$\begin{array}{llll}\text { khôy } & \text { dày } & \text { hùucák } & \text { káp } \\ \text { 1st pers. pron. } & \text { to get to to know (s.one) } & \text { with } \\ \text { láaw } & \text { jūu } & \text { hóonhian } & \\ \text { 3rd pers. pron. } & \text { location marker } & \text { school } & \\ \text { 'I got to know her at school' } & & \end{array}$

\section{Recent History}

When the boundaries of present-day Laos were drawn up in 1893 under the terms of a FrancoSiamese treaty, the Lao-speaking population was divided in two, the majority paradoxically being in northeast Thailand. The French brought in Vietnamese to carry out much of the administration of their colony, and with French the medium for what little postprimary education existed, the Lao language suffered a loss of prestige, even among many of its own speakers. The decline of French influence and the rise of nationalism in the aftermath of World War II helped to improve the status of Lao. Although the communist government, which came to power in 1975, has Lao-ized the education system, introduced adult literacy programmes and attempted to teach Lao to the country's ethnic minorities, literacy rates remain low.

See also: Laos: Language Situation; Southeast Asia as a Linguistic Area; Tai Languages; Thailand: Language Situation.

\section{Bibliography}

Chamberlain J R (1978). 'Language standardisation in Laos.' In Perez A Q, Santiago A O \& Nguyen Dang Liem (eds.) Papers from the conference on the standardisation of Asian languages, Manila, Philippines, December 16-21, 1974. Pacific Linguistics, Series C - no. 47. Canberra: Research School of Pacific Studies, Australian National University.

Hoshino T \& Marcus R (1981). Lao for beginners. Rutland, Vermont. Charles E. Tuttle.

Enfield N J (1999). 'Lao as a national language.' In Evans G (ed.) Laos: Culture and society. Chiang Mai. Thailand: Silkworm Books. 258-290.

Morev L N, Moskalyov A A \& Plam Y Y (1979). The Lao language. Moscow: USSR Academy of Sciences, Institute of Oriental Studies.

Smalley W A (1994). Linguistic diversity and national unity: language ecology in Thailand. Chicago: University of Chicago Press.

Yates W G \& Souksomboun S (1970). Lao basic course. Washington, D.C.: Foreign Service Institute.

\title{
Laos: Language Situation
}

\author{
N J Enfield, Max Planck Institute for Psycholinguistics, \\ Nijmegen, The Netherlands \\ (c) 2006 Elsevier Ltd. All rights reserved.
}

The Lao People's Democratic Republic (Laos) is home to languages from at least four different 'genetic' groups: Tai (southwestern and northern branches), Mon-Khmer (Bahnaric, Katuic, Vietic, Khmuic, and Palaungic branches), Hmong-Mien (Hmongic and Mienic branches), and Tibeto-Burman (Lolo-Burmese branch). The precise number of languages spoken in the country is not known, due mainly to a lack of empirical data. Estimates vary between around 70 and around 120 distinct languages (Ethnologue 2004 lists 82). For a country of its size (smaller than the United Kingdom) and population (less than 5 million), Laos features a very high degree of linguistic diversity in global terms. This diversity is greatest in the country's hill and mountain areas, which account for some $70 \%$ of the land mass. Flatter stretches of land along rivers (especially along the Mekong River) are dominated by speakers of Lao. 


\section{Historical Background}

Mon-Khmer languages appear to have been spoken in Laos longer than languages of other families. They show greater geographical spread and greater internal diversity. This is particularly apparent among languages of the Vietic, Katuic, and Bahnaric subgroups spoken throughout upland areas of the country's south. Many of these languages are near extinction, with very few remaining speakers (e.g., Thémarou, with only a couple of dozen speakers). Other languages, while small, are still being learned by children (e.g., Tariang (Talieng) with about 4000 speakers), although none show the vibrancy of the northern Mon-Khmer language $\mathrm{Kmhmu}(\mathrm{Khmu})$, with some 300000 speakers throughout northern Laos. Tai languages such as Lao have their origins in southwest migrations of Tai speakers from southwestern China, beginning some 2000 years ago (Enfield, 2003: 47-50). Like their modern descendents, these incoming Tai speakers were in search of flat riverside land ideal for their trademark 'ditch-dike' system of wet-rice cultivation. The success of Tai languages and their speakers is attested to by their present dominance of the region, with Lao the official national language of Laos (Enfield, 1999), spoken as a first language by around half the population (more than two million people). (There are also approximately 20 million residents of northeast Thailand whose native dialects are closely related to Lao.) Hmong-Mien speakers are the newest arrivals in Laos, descended from migrants coming southwards from China within the last 200 years (Culas and Michaud, 2004).

\section{Language Contact, Sociolinguistics, Multilingualism}

Laos's high degree of linguistic diversity results in intensive language contact in most parts of the country. Upland peoples maintain structured social relations across ethnicities and language backgrounds, and are normally multilingual (Bradley, 2003). By contrast, lowland-dwelling people of Lao ethnicity tend to be monolingual. Some minority languages serve as contact languages within restricted upland areas. For example, Ngkriang (Ngeq) is used in interaction among several Katuic ethnic groups in isolated Kalum district, Sekong province.

Lao is the official language of administration, education, and major economic activity, and hence all minority communities have regular contact with Lao. Minority men are often more skilled than women and children in speaking Lao due to greater contact with the language, for example, during military service. Official promotion of Lao as a national language is served in part by the development of Lao language media and education, but this is slow thanks to the country's very weak infrastructure. Authorities widely encourage (and occasionally force) migration by minority peoples from upland areas to more accessible lowlands, ostensibly to ease the burden of social development in this poor nation. Internal migration is widespread, and in many cases this accelerates the process of attrition and loss of minority languages, due to division of already fragile speech communities and their resettlement together with speakers of other languages, in closer contact with the Lao-speaking world. The result is a widespread and rapid shift to Lao.

The two most prominent and vibrant minority languages of Laos are Hmong and Kmhmu, both spoken by large populations, mainly in northern Laos. Hmong speakers in particular show no signs of abandoning their language in favor of Lao. Hmong has a roman orthography that is taught unofficially and is in widespread use in Hmong society (e.g., in advertising, development, private correspondence, etc.). This contravenes the Lao government's official stipulation that no minority language is to be written in any orthography other than the Indic-based Lao script.

International languages with a significant presence in Laos include Thai and Vietnamese. Laos's longest borders are with Thailand to the west and Vietnam to the east. Lowland communities along the Mekong River are in intensive contact with Thai via electronic media, as well as through seasonal migration of Lao workers to Thailand. Thai and Lao are essentially dialects, making Thai especially accessible to Lao speakers. Vietnamese is less widely spoken as a second language (despite large urban communities of expatriate Vietnamese in the lowlands), but is used for economic purposes by many minority peoples living along the Vietnamese border. Through the colonial period of 1893 to 1954 (Evans, 2002), French was widely used in national education and administration. The use of French as an international language has since steadily diminished in favor of English.

\section{Linguistic Research and Reference Materials}

Comparatively little scientific research has been conducted on the languages of Laos. Descriptive studies of Lao include traditional European-style grammars (e.g., Hospitalier, 1937; Royal Lao Government, 1972; Reinhorn, 1980), dictionaries (Kerr, 1972; Reinhorn, 1970; Rehbein and Sayaseng, 2000), pedagogical materials (e.g., Yates and Sayasithsena, 1970; 
Hoshino and Marcus, 1981), and work of a more technical linguistic nature (e.g., Roffe, 1946; Morev et al., 1972; Crisfield, 1978; Wayland, 1996; Osatananda, 1997; Enfield, 2003, 2005). Available research on minority languages includes dictionaries (e.g., Lindell et al., 1994; Preisig et al., 1994 [Kmhmu]; Ferlus, 1999 [Nhaheun]), text collections (e.g., Costello and IRLCS, 1993 [Katu]), grammatical descriptions (e.g., Jacq, in press [Jruq]; Enfield, 2004 [Kri]), comparative word lists (e.g., Kingsada and Shintani, 1999; Wright, 2003), and historicalcoparative work (e.g., Diffloth, 1982; Peiros, 1996; Sidwell, 2000; L-Thongkhum, 2002). Field research on languages of Laos is hampered not only by difficulties of transport and communications but also by severe restrictions imposed by the socialist government on research in the social sciences.

See also: Language Change and Language Contact; Lao; Mon-Khmer Languages; Multilingualism: Pragmatic Aspects; Standardization; Tai Languages.

Language Maps (Appendix 1): Maps 105, 106.

\section{Bibliography}

Bradley D (2003). 'Language and culture of minority groups.' In Goudineau Y (ed.) Laos and ethnic minority cultures: promoting heritage. Paris: UNESCO. 45-68.

Costello N \& Institute of Research on Lao Culture Society (1993). Katu folktales and society. Vientiane: Ministry of Information and Culture.

Crisfield A G (1978). Sound symbolism and the expressive words of Lao. Ph.D. diss., University of Hawaii.

Culas C \& Michaud J (2004). 'A contribution to the study of Hmong (Miao) migrations and history.' In Tapp N, Michaud J, Culas C \& Lee G Y (eds.) Hmong/Miao in Asia. Chiang Mai: Silkworm Books. 61-96.

Diffloth G (1982). 'Registres, dévoisement, timbres vocaliques: leur histoire en Katouique.' Mon-Khmer Studies 11, 47-82.

Enfield N J (1999). 'Lao as a national language.' In Evans G (ed.) Laos: culture and society. Chiang Mai, Silkworm Books. 258-290.

Enfield N J (2003). Linguistic epidemiology: semantics and grammar of language contact in mainland Southeast Asia. London: Routledge Curzon.

Enfield N J (2004). Sketch of Kri, a Vietic language of Khammouan. Typescript, MPI for Psycholinguistics, Nijmegen, The Netherlands.

Enfield N J (2005). 'Verbs and multi-verb sequences in Lao.' In Diller A V N \& Edmondson J (eds.) Survey of the TaiKadai Language family. London: Routledge Curzon.

Evans G (2002). A short history of Laos: the land in between. Chiang Mai: Silkworm Books.

Ferlus M (1999). Nhaheun-French-English lexicon. Jacq P \& Sidwell P (trans. and ed.). München: Lincom Europa.
Hoshino T \& Marcus R (1981). Lao for beginners: an introduction to the spoken and written language of Laos. Rutland/Tokyo: Tuttle.

Hospitalier J J (1937). Grammaire laotienne. Paris: Imprimerie National.

Jacq P (in press). A description of Jru'(Loven) (2 vols). Mahidol University [Mon-Khmer Studies Special Publication].

Kerr A D (1972). Lao-English Dictionary. Washington, DC: Catholic University of America Press.

Kingsada T \& Shintani T (eds.) (1999). Basic vocabularies of the languages spoken in Phongsaly, Lao PDR. Tokyo: Institute for the Study of Languages and Cultures of Asia and Africa.

L-Thongkhum T (2002). 'A brief look at the thirteen MonKhmer languages of Xekong province, southern Laos.' In Bauer R S (ed.) Collected papers on Southeast Asian and Pacific languages (Pacific Linguistics 530). Canberra: Research School of Pacific and Asian Studies, ANU. 95108.

Lindell K, Damrong T, Kingsada T \& Sainyawong S (1994). Khamu-Lao dictionary. Vientiane: Ministry of Information and Culture.

Morev L N, Moskalev A S \& Plam Y Y (1972). The Lao language. Moscow: Nanka (Glavnaja Redakcija Vostochnoj Literatury). [in Russian.]

Nginn P S (1984). Elements de grammaire laotienne. Paris: Sudestasie.

Osatananda V (1997). Tone in Vientiane Lao. Ph.D. diss., University of Hawaii.

Peiros I (1996). Katuic comparative dictionary. Canberra: Australian National University. [Pacific Linguistics Series C-132.]

Preisig E, Sayavong S \& Simana' S (1994). Kmbmu'-LaoFrench-English dictionary. Vientiane: Ministry of Information and Culture.

Rehbein B \& Sayaseng S (2000). Wörterbuch LaotischDeutsch/Deutsch-Laotisch. Hamburg: Buske.

Reinhorn M (1970). Dictionnaire Laotien-Francais. Paris: Centre de la Recherché Scientifique.

Reinhorn M (1980). Grammaire de la langue Lao. Paris: Institute National des Langues et Civilisations Orientales, Université de la Sorbonne Nouvelle.

Royal Lao Government (1972). Lao Grammar (4 vols). Vientiane: Royal Academy, Ministry of Education [in Lao language].

Roffe E G (1946). 'The phonemic structure of Lao.' Journal of the American Oriental Society 66, 289-295.

Sidwell P (2000). Proto South Bahnaric: a reconstruction of a Mon-Khmer language of Indo-China: vol. 501. Canberra: Pacific Linguistics.

Wayland R (1996). 'Lao expressives.' Mon-Khmer Studies 26, 217-231.

Wright P S (2003). 'Singsali (Phunoi) speech varieties of Phongsali province.' Language and Life Journal 1, 62-73.

Yates W G \& Sayasithsena S (1970). Lao basic course ( 2 vols). Washington, DC: Foreign Service Institute. 